Jurnal Indonesia Sosial Teknologi: p-ISSN: 2723 - 6609

e-ISSN : 2745-5254

Vol. 2, No. 7 Juli 2021

\title{
EKSISTENSI TRADISI SERAK GULO DI KOTA PADANG
}

\author{
Seski Bakti Syafeli \\ Universitas Pendidikan Indonesia \\ Email: seskibs@upi.edu
}

\begin{abstract}
Abstrak
Masyarakat Muhammadan merupakan salah satu paguyuban yang ada di Kota Padang. Dalam upaya pembauran dengan etnis lain maka mereka melaksanakan tradisi serak gulo yang dibawa dari Gujarat oleh nenek moyangnya sebagai tanda syukur atas rezeki yanag mereka dapatkan dalam kurun satu tahun. Pelaksanaan serak gulo menghimpun berbagai kalangan mulai dari beragam etnis, strata, serta budaya yang berbeda. Pelaksanaan serak gulo memberikan keceriaan dan kegembiraan bagi masyarakat antar etnis yang ada di Kota Padang. Tujuan penelitian ini adalah untuk mendapatkan gambaran secara mendalam mengenai eksistensi tradisi serak gulo dalam mewujudkan integrasi sosial antar etnis di Kota Padang. Penelitian ini memakai pendekatan kualitatif dan deskriptif analisis. Dalam penelitian ini peneliti mengumpulkan data dengan menggunakan teknik observasi, wawancara dan studi dokumentasi. Hasil penelitian menunjukkan, pertama bentuk tradisi serak gulo ini memiliki dua tahapan yaitu tahap persiapan kegiatan serak gulo dan tahap pelaksanaan kegiatan serak gulo. Kedua, pemerintah juga berperan dalam pelaksanaan serak gulo meliputi penyebaran informasi kegiatan acara serak gulo, penganggaran dana dan penyediaan fasilitas keamanan. Ketiga, adapun kontribusi serak gulo dalam mewujudkan integrasi antar etnis di Kota Padang meliputi (1) Meningkatnya interaksi antar etnis di Kota Padang (2) Menguatnya rasa identitas sebagai bagian dari masyarakat Kota Padang (3) Menguatnya rasa solidaritas dan toleransi (4) Terjadinya amalgamas
\end{abstract}

Kata Kunci: serak gulo; masyarakat Muhammadan; integrasi sosial

\section{Abstract}

The tradition serak gulo contributed to the impact of social integration in interethnic life in the city of Padang. In tradition serak gulo, many people come with high enthusiasm. The government also takes part in this serak gulo tradition. Serak gulo is an activity carried out by the Muhammadan community in order to fulfill their vows for the sustenance they have received from Allah SWT. This research uses a qualitative approach with the case study method. The data collection stage is in the form of interviews, observations, and documentation. The results of the study looked at the implementation of the tradition serak gulo and saw the role of the government in the implementation of thetradition serak gulo, as well as the impact of the serak gulo in realizing social integration in the city of Padang. The findings in this study are that serak gulo has a major impact on inter-ethnic social integration in the city of Padang. The embodiment of social integration can be seen from internal and external aspects. Internally, the tradition serak gulo has the 
following impacts: a) preserving thetradition serak gulo, b) establishing friendships, pexternal factors are: a) increased interaction between communities, b) strengthened sense of solidarity and tolerance between ethnicities, $c$ ) amalgamation occurs. Apart from the participation of the community in this activity, the husky gulo is also able to reduce the differences that exist between ethnic groups in the city of Padang.

Keywords: serak gulo; muhammadan community; social integration

\section{Pendahuluan}

Kota Padang merupakan salah satu kota dengan penduduk yang mempunyai keberagaman etnis, agama, ras, suku, dan lain sebagainya. Terjadinya keberagaman ini dikarenakan banyak faktor, diantaranya faktor geografis. Tercatat dalam sejarah Kota Padang menjadi salah satu tempat pemberhentian bagi penjajah maupun para pedagang melalui jalur laut dalam waktu yang tidak sebentar. Sehingga tidak dapat dihindari muncul faktor yang kedua yaitu terjadinya amalgamasi dan asimilasi. Ketiga, perbedaan mata pencaharian, perbedaan bentuk geografis atau wilayah menjadikan para pendatang membentuk sistem mata pencaharian yang berbeda dengan masyarakat asli agar kebutuhan hidupnya terpenuhi (Abidin, 2016).

Faktor pertama menjadi alasan masuknya masyarakat pendatang seperti etnis Cina, etnis India, Etnis Arab, Suku Jawa, dan Suku Nias ke Kota Padang (Safwan, Taher, \& Asnan, 1987). Masyarakat pendatang biasanya tinggal secara berkelompok pada sebuah wilayah sesuai dengan etnisnya masing-masing. Sampai sekarang sebagian besar masyarakat pendatang masih hidup berkelompok di Kecamatan Padang Selatan. Lokasi ini biasanya disebut daerah Pondok, berasal dari kata pondokan yang berarti tempat istirahat atau tempat tinggal. Kawasan ini dipilih karena terletak di tepi sungai yang menjadi tempat pemberhentian kapal-kapal para pedagang. Etnis yang bermukim di daerah pondok adalah di etnis India Muslim dengan sebutan kampung Keling, Cina dengan sebutan kampung Cina, Nias dengan sebutan kampung Nias, dan Jawa disebut kampung Jawa. Sehingga tidak heran jika wilayah Padang Selatan dapat berkembang dengan pesat karena menjadi pusat perdagangan dan objek wisata.

Perbedaan latar belakang sosial dan budaya tetap bisa menjadikan mereka hidup berdampingan dan hampir tidak ada konflik sama sekali (Juditha, 2015). Bahkan jika ada pergelaran tradisi dari salah satu etnis, etnis lain datang untuk memeriahkan tradisi itu. Seperti selaju sampan yang merupakan tradisi dari etnis Minangkabau juga diramaikan dan dinikmati acaranya oleh masyarakat dari etnis lain. Begitu juga perayaan serak gulo pada tradisi etnis India muslim dan tradisi cap go meh oleh etnis Tionghoa. Tiga etnis ini saling melengkapi satu sama lain. Masing-masing etnis hampir tidak memiliki stereotip negatif kepada etnis lain, karena suasana yang diciptakan dalam bermasyarakat adalah suasana yang positif.

Serak gulo menjadi salah satu kegiatan tahunan yang terus dilakukan pada akhir Jumadil Akhir pada kalender Hijriah oleh para masyarakat Muhammadan di depan masjid Muhammadan Pasar Gadang. Etnis India muslim menamai kelompoknya 
dengan masyarakat Muhammadan. Perubahan tersebut dilakukan karena jika dipanggil dengan etnis India mempunyai konotasi mereka menganut agama Hindu atau Budha, sedangkan jika dipanggil dengan nama Muhammadan tentu masyarakat akan tahu bahwa mereka menganut agama Islam. Kegiatan serak gulo dilirik oleh Pemerintah Kota Padang karena pelaksanaannya begitu meriah dan sangat menarik. Uniknya serak gulo juga masuk sebagai kalender tahunan pemerintah Kota Padang. Selain menarik para wisatawan, upaya ini dilakukan pemerintah agar budaya yang telah mereka lakukan sejak lama tidak hilang. Serak gulo memberikan pengaruh yang positif bagi masyarakat masyarakat Muhammadan dengan etnis sekitarnya. Sehingga terjalin komunikasi yang terbuka tanpa ada yang membatasi mereka.

Pengaruh positif ini memberikan respon yang baik pula kepada etnis lain. Pelaksanaan dan perayaan tradisi masyarakat Kota Padang dipersilahkan hadir melihat dan ikut serta mengikuti kegiatan yang dilakukan. Gula yang terkumpul bukan hanya sumbangan dari masyarakat Muhammadan saja, melainkan etnis lain juga boleh menyumbang donasi baik itu berupa gula, jeruk, uang dan sebagainya yang dirasa perlu. Masyarakat Muhammadan dapat dikatakan berhasil dalam mengambil hati masyarakat Kota Padang. Hal ini dapat peneliti rasakan ditandai dengan kehidupan yang rukun, damai, saling toleransi, saling bersilaturahmi, bahkan saling membantu antar sesama. Perasaan tersebut membuktikan bahwa perbedaan yang ada akan memberikan kebaikankebaikan yang sangat positif sehingga harus dijaga dan dihargai (Hardianto, 2020).

Keberadaan masyarakat Muhammadan tidak menimbulkan kecemasan bagi masyarakat setempat, malah sebaliknya mereka sebagai salah satu agen dalam mewujudkan integrasi sosial antar etnis di Kota Padang. Gambaran mengenai kehidupan masyarakat Muhammadan yang ada di Padang sangat bisa dijadikan sebagai contoh dalam kehidupan masyarakat multikultural, karena pada dasarnya setiap tempat memiliki kondisi sosial budaya yang berbeda-beda. Masyarakat yang terintegrasi atas dasar kesepakatan dari para anggotanya akan nilai-nilai kemasyarakatan tertentu yang mempunyai kemampuan mengatasi perbedaan-perbedaan sehingga masyarakat tersebut dipandang sebagai suatu sistem yang secara fungsional terintegrasi dalam suatu keseimbangan. Dengan demikian "masyarakat adalah merupakan kumpulan sistemsistem sosial yang satu sama lain berhubungan dan saling ketergantungan" (Grathoff, 2000). Kegiatan serak gulo yang dilakukan oleh masyarakat Muhammadan sangat berhubungan sekali dengan teori struktural fungsional yang dibesarkan oleh Talcott Parsons.

Perspektif ini menganut bahwa setiap elemen mempunyai fungsinya masingmasing. Apabila salah satu sistem pincang, maka seluruh aspek akan terganggu. Pada struktural fungsional terdapat kebutuhan-kebutuhan yang harus dicapai ketika mempertahankan hidup dibarengi dengan struktur yang sesuai dengan kehidupannya dalam memenuhi sebuah kebutuhan. Terdapat satu proposisi sangat penting dari teori ini sebuah struktur pasti akan selalu menpunyai proses menciptakan keseimbangan.

Dengan adanya keberagaman akan mendorong masyarakat Kota Padang untuk saling menghargai dan toleransi satu sama lain. Nilai toleransi menjadi sebuah nilai 
unggul dalam menciptakan kedamaian pada keyakinan tiap individu (Hasan, 2016). Secara keseluruhan serak gulo mempunyai dampak integrasi sosial dan dirasakan oleh tiap etnis, baik itu masyarakat Muhammadan, masyarakat Kota Padang dan pemerintah Kota Padang yang akan mengangkat eksistesi tradisi serak gulo ini nantinya. (Sari, 2011) meneliti mengenai bagaimana sejarah timbulnya tradisi serak gulo, melihat bagaimana proses tradisi tersebut dilaksanakan, serta nilai-nilai yang terkandung dalam tradisi serak gulo. Seiring melestarikan tradisi yang menjadi program pemerintah (Faisal, 2020) meneliti mengenai ruang-ruang perjumpaan yang dilakukan oleh antar etnis dan agama. Artinya, intoleransi juga masih dapat terjadi dengan kelompok masyarakat yang jarang melakukan dialog lintas agama dan budaya.

Penulis ingin melihat eksistensi tradisi serak gulo di Kota Padang sebagai keterbaharuan penelitian yang belum disorot pada peneliti sebelumnya. Terdapatnya kelompok minoritas dan mayoritas terjadi karena adanya keberagaman (Nurhayati \& Agustina, 2020). Masyarakat Muhammadan termasuk kelompok minoritas yang dalam jumlah anggotanya hanya sedikit di banding kelompok masyarakat lain. Walaupun hanya berjumlah sedikit, masyarakat Muhammadan tidak pernah lelah untuk melestarikan budaya yang dibawa oleh nenek moyang mereka. Mereka menyepakati untuk selalu melaksanakan tradisi ini demi menjaga eksistensi tradisi tersebut. Upaya yang masyarakat Muhammadan lakukan adalah usaha pembauran dengan masyarakat asli yang tinggal di lingkungan tersebut.

Inti dari keberagaman ini adalah kesediaan dari kelompok satu dengan kelompok yang lainnya sebagai suatu kesatuan, tanpa memandang adanya perbedaan latar belakang dan budaya. Terciptanya sebuah kesatuan dalam kehidupan membentuk sebuah nilai dan norma yang dianut bersama dalam bersikap, keteraturan dan berperilaku koperatif (Fukuyama, 2002). Terlihat pada saat pelaksanaan ritual serak gulo ini masyarakat terlihat saling membantu dalam mempersiapkan acara secara bersama-sama. Hal ini menunjukkan bahwa menjadi minoritas bukanlah sebagai penghalang untuk melestarikan kearifan lokal yang dibawa oleh nenek moyangnya, akan tetapi dapat dipandang sebagai sebuah keberagaman budaya yang akan menjadi

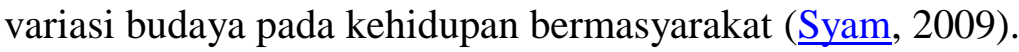

Sehingga dari latar belakang di atas dapat diambil judul "Eksistensi Serak Gulo Di Kota Padang", peneliti mencoba menggali lebih dalam tentang bagaimana eksistensi tradisi serak gulo yang hanya ada di kota Padang. Tujuan agar serak gulo dapat dijadikan sebagai salah satu contoh tradisi yang mampu eksis dan memberikan dampak terhadap kehidupan bermasyarakat.

\section{Metode Penelitian}

Tujuan penelitian ini adalah untuk mendapatkan gambaran secara mendalam mengenai eksistensi tradisi serak gulo dalam mewujudkan integrasi sosial antar etnis di Kota Padang. Penelitian ini menggunakan pendekatan kualitatif dan metode deskripsi analisis. Pengumpulan data menggunakan dengan teknik observasi, wawancara dan dokumentasi (Sugiyono, 2014). Peneliti menggunakan purposive sampling dengan 
mengambil beberapa informan yang mampu menjawab kebutuhan penelitian (Sugiyono, 2012). Informan penelitian ini adalah ketua masyarakat Muhammadan, ketua LKAAM (Lembaga Kerapatan Adat Alam Minangkabau), Dinas Kebudayaan dan Pariwisata Kota Padang, Camat Padang Selatan, dan masyarakat yang berada di daerah Pasar Gadang. Pihak yang peneliti sebutkan merupakan orang yang mempunyai informasi dan pengetahuan dalam memberi informasi bahkan sebagai penuntun dan memberikan akses kepada peneliti dalam melaksanakan penelitian mengenai serak gulo ini (Schwandt, 2007).

\section{Hasil dan Pembahasan}

Serak gulo telah menjadi salah satu identitas budaya khas masyarakat Muhammadan yang menunjukkan bagaimana sebuah komitmen oleh kelompok minoritas dalam menginternalisasikan nilai-nilai kebersamaan, persatuan dalam menyambut keberkahan dengan membagikan gula kepada semua partisipan acara. Keberkahan yang diajar oleh Wali Allah Sahul Hamid akhirnya berbuah manis dan memang bisa dirasakan oleh semua kalangan masyarakat terkhususnya masyarakat Kota Padang. Adanya keberadaan serak gulo, masyarakat Muhammadan mampu untuk lebih bersikap terbuka dengan masyarakat yang lain. Mereka selalu berhati-hati dalam bersikap, karena tidak mau menyinggung atau membuat masalah sekecil apapun dengan masyarakat lain.

Adapun prosesi tradisi pelaksanaan tradisi serak gulo masyarakat Muhammadan, khususnya yang ada di Kota Padang terdiri dari tahap persiapan dan tahap pelaksanaan kegiatan. Hal ini dapat diuraikan sebagai berikut:

1) Tahap Persiapan Kegiatan Serak Gulo Oleh Masyarakat Muhammadan Kota Padang

a. Pengumuman Kegiatan Serak gulo

Kegiatan serak gulo biasanya diumumkan dua bulan sebelum kegiatan dilaksanakan. Serak gulo dapat dihitung tiga bulan sebelum memasuki bulan puasa. Himpunan Keluarga Muhammadan (HKM) memberitahu keluarga yang tidak berdomisili di Kota Padang, dan juga membuat spanduk terkait kegiatan serak gulo dan dipasang di depan teras masjid Muhammadan. Sosialisasi tradisi ini juga dilakukan oleh setiap orang tua kepada anaknya, agar mereka tertarik dengan budaya yang dibawa oleh nenek moyangnya. Akan lebih seru lagi jika orang tertua dalam kelompok Muhammadan seperti nenek dan kakek menceritakan secara detail bagaimana kemeriahan serak gulo yang telah dilakukan ratusan tahun yang lalu. Sehingga tidak heran, pada pelaksanaanya anak-anak Muhammadan sangat gembira tidak sabar untuk menunggu hari pelaksanaan.

b. Pengumpulan Gula

Masyarakat yang ingin bernazar sudah bisa memberikan gula kepada panitia. Gula biasanya dikumpulkan di salah satu rumah tetua masyarakat Muhammadan yang terletak di depan masjid Muhammadan. Pemilihan gula untuk diberikan kepada masyarakat ada filosofinya. Selain mengenang kebaikan Sahul Hamid, alasan dipilihnya gula berharap sesuatu yang manis. Tidak dapat 
dipungkiri jika niat orang yang bernazar ini adalah dimudahkan untuk mendapatkan pendamping hidup, diterima menjadi Pegawai Negeri Sipil, bisa naik haji, dan sebagainya. Orang yang bernazar memberikan gula tidak hanya dari masyarakat Muhammadan saja, tapi terbuka juga untuk umum. Gula bisa saja sumbangan dari pemerintah, etnis Tionghoa, ataupun masyarakat Minangkabau dengan syarat mereka telah berniat baik ketika memberikan gula tersebut. Gula yang terkumpul pada kegiatan serak gulo tahun 2020 berjumlah kurang lebih 7 ton. Meskipun tidak sebanyak tahun 2019 yang berjumlah 9 ton, tapi tidak mengurangi nilai kebersamaan dan kemeriahan kegiatan acara serak gulo.

Gula yang telah terkumpul dimasukkan ke dalam kain perca warna warni oleh anak-anak keturunan Muhammadan. Mereka ikut andil dan bersemangat dalam memasukkan gula ke dalam kain perca. Anak-anak memasukkan gula mulai dari jam 9 pagi hingga sudah mulai merasa capek. Apabila proses pembungkusan gula ke dalam kain perca sudah selesai, maka kain perca yang berisikan gula akan di tumpuk tinggi agar tidak memenuhi seluruh teras rumah, panitia berjaga-jaga jika masih ada yang bermiat memberikan gula ketika hari $\mathrm{H}$ sebelum kegiatan acara dimulai. Apabila dirasa sudah mendekati jam pelaksanaan acara, maka gula tersebut akan dimasukkan ke dalam kantong kresek dan karung guna dibawa ke atas atap masjid ketika proses pembagian serak gulo.

c. Masak Bersama

Pada waktu yang sama, rombongan ibu-ibu akan sibuk di dapur untuk mengelola konsumsi dan persiapan makanan minuman kegiatan serak gulo yang akan disajikan ketika berdoa bersama dan di halaman mesjid. Biasanya mereka bersama-sama memasak di salah satu rumah tetua dekat dengan masjid Muhammadan. Mereka memasak makanan dan minuman khas India halal dalam jumlah yang lumayan banyak. Adapun makanan dan minuman yang dibuat adalah (1) air asam yaitu minuman yang terbuat dari jeruk nipis diberi bubuk khas berwarna cokelat. (2) ampiang terbuat dari beras ketan.

2) Tahap Pelaksanaan Kegiatan Serak Gulo Masyarakat Muhammadan Kota Padang

a. Dekorasi Tempat Kegiatan Acara Serak Gulo

Panitia bisanya sudah mulai mendekorasi tempat jam 6 pagi sampai jam 2 siang. Tim dekorasi biasanya diberikan tanggung jawab kepada laki-laki. Panitia akan memasang tirai hiasan di sekitaran masjid dan membentangkan karpet panjang berwarna merah tepat di jalan raya depan teras Mesjid Muhammadan. Karpet merah tersebut akan menjadi tempat mimbar yang digunakan sebagai panggung acara.

b. Pembukaan Acara Resmi Serak Gulo dan Doa Bersama

Kegiatan serak gulo dijadwalkan oleh panitia setelah solat Ashar. Biasanya semua panitia sudah berpakaian rapi dan hadir sebelum jam tiga siang. Setelah adzan dikumandangkan, panitia laki-laki bersama-sama solat berjamaah di 
masjid Muhammadan. Sedangkan ibu-ibu lebih sibuk menuangkan hidangan yang dimasak sehari sebelum kegiatan di pelataraan masjid serta teras rumah yang dijadikan tempat do'a bersama. Tidak lebih dari 15 menit para tamu undangan dari pemerintah Kota Padang datang, seperti: Bapak Nasrul Abit sebagai wakil gubernur Sumatera Barat, Bapak Mahyeldi sebagai Walikota Padang, Bapak Teddy Kurniawan sebagai Camat Padang Selatan, Bapak Eri Sanjaya sebagai Camat Padang Barat, dan dihadiri juga oleh Anggota DPR RI Bapak Mardani Alisera. Setelah dibuka secara resmi, para tamu undangan dan para tetua dari masyarakat Muhammdan langsung berdiri dan berjalan mennuju rumah tetua lalu menggelar doa bersama di rumah yang dianggap sebagai rumah gadang masyarakat Muhammadan.

c. Pemasangan Bendera

Bendera yang dipasang berwarna hijau. Alasan bendera berwarna hijau karena agama Islam identik dengan warna hijau yang mempunyai makna suci. Bendera di bentuk dengan potongan segitiga, dan terdapat gambar bulan bintang. Bulan bintang menandakan kebesaran tuhan yang telah memberikan penerangan dan petunjuk kepada umatnya. Pada bendera terdapat cap tangan masyarakat Muhammadan yang telah melakukan niat nazar untuk menyumbangkan gula pada kegiatan serak gulo. Cap tangan pada bendera tidak memakai tinta spidol tetapi menggunakan serbuk bubuk kayu cendana.

d. Prosesi Serak gulo

Panitia yang bertugas akan menyebar ke tenda kecil berwarna hijau yang sudah disiapkan sehingga tidak berkumpul di satu atap mesjid saja, dimaksudkan agar gula yang dilempar dapat terbagi rata ke semua penduduk. Masyarakat yang datang pun semangatnya juga tidak kalah dengan masyarakat Muhammadan, masyarakat yang hadir terlihat sangat antusias sekali. Terlihat dari persiapan masyarakat yang akan berpartisipasi, seperti membawa kantong kresek, karung, ember, dan memakai helm. Semua masyarakat yang hadir saling berebut gula sehingga kemeriahan acara serak gulo sangat terasa. Jika ada yang jatuh ketika mengambil gula, maka yang lain akan menolong yang jatuh. Terkadang diselingi dengan gelak tawa para masyarakat yang mengikuti serak gulo.

Ketika tahun 2016 akhir, Dinas Pariwisata dan Kebudayaan Kota Padang melakukan banyak mengevaluasi kinerja terkait bidang pariwisata. Pembuatan kalender event tahunan ini adalah salah satu peran pemerintah dalam mengupayakan menyebarkan informasi untuk masyarakat di Kota Padang. Selain itu para wisatawan juga bisa mengetahui informasi kegiatan-kegiatan apa saja yang dilaksanakan dalam kurun waktu satu tahun dari bulan Januari hingga bulan Desember. Setelah informasi didapatkan oleh masyarakat dan wisatawan, diharapkan masyarakat lebih melek dan sadar keberagaman etnis dan budaya di Kota Padang. Selain sebagai mediator dan menyusun kalender tahunan yang bertujuan sebagai pengingat acara budaya, peran pemerintah selanjutnya merupakan hal yang paling penting mengenai yaitu sebagai fasilitator sarana dan 
prasarana. Hal ini menjadi penting sekali karena terkait dengan pelayanan kebutuhan ataupun pendanaan kegiatan acara. Dinas Pariwisata dan Kebudayaan biasanya sudah menganggarkan biaya yang biasanya digunakan kelancaran acara suatu kegiatan budaya. Biasanya ketika kegiatan budaya akan dilakukan, para panitia dari acara tersebut akan mengajukan proposal kegiatan kepada Dinas Pariwisata dan Kebudayaan guna meminta bantuan dari pemerintah.

Secara keseluruhan tradisi serak gulo memberikan banyak dampak secara internal maupun eksternal pada persatuan antar etnis yang ada di Kota Padang. Dampak internal dirasakan langsung oleh masyarakat Muhammadan selaku penyelenggara acara, adalah:

a) Pelestarian tradisi serak gulo

Kegiatan serak gulo yang dilakukan masyarakat Muhammadan adalah bentuk patuh dan hormat masyarakat Muhamamdan pada nenek moyang yang telah mengamanatkan untuk tetap melaksanakan tradisi ini dalam keadaan apapun. Adanya keharusan untuk tetap melaksanakan kegiataan ini salah satu pemikiran panjang nenek moyang Muhammadan terhadap generasinya.

b) Menjalin Silaturahmi

Pada dasarnya manusia selalu bekerja untuk memenuhi kebutuhan keluarganya, sehingga seringkali lalai untuk menjalin silaturahmi kepada keluarga, bahkan dengan tetangga sendiri. Hal ini menjadikan seseorang mempunyai sifat individualism, yang akan membawa dampak buruk dalam lingkungan sosial. Tradisi serak gulo yang ada di Kelurahan Pasar gadang mampu membantah pernyataan di atas. Masyarakat Muhammadan sebenarnya melakukan silaturahmi tidak hanya menunggu momentum serak gulo saja. Tetapi melalui serak gulo hubungan silaturakmi antar masyarakat Muhammadan secara keluarga besar terjalin lebih erat.

c) Menguatnya Rasa Identitas Sebagai Bagian Dari Masyarakat

Banyaknya partisipan pada perayaan serak gulo adalah salah satu bentuk menyatunya rasa identitas antara masyarakat bahwa mereka berada di satu bangsa. Bahasa yang mereka pakai sehari-hari kepada keluarga mereka adalah bahasa campuran Minang-Indonesia. Mereka tidak terlalu faseh dalam berbahasa Minang, tetapi mengerti apa yang dikomunikasikan oleh orang lain. Masyarakat Muhammadan tetap menyebut diri mereka adalah orang India keturunan Muslim, tapi bangsa mereka tetap satu, yaitu Indonesia. Begitu juga yang terjadi dengan etnis lain seperti Tionghoa. Mereka mengetahui bahwa nenek moyangnya berasal dari negara lain, tetapi secara turun temurun mereka sudah menjadi bangsa yang satu, yaitu Indonesia. 
Dampak eksternal tradisi serak gulo terhadap kehidupan sosial pada masyarakat Kota Padang adalah:

a. Interaksi Antar Masyarakat Meningkat

Seorang individu dalam hidup di masyarakat cenderung melihat dengan siapa orang berinteraksi, bagaimana bentuk tubuh mereka, pakaian mereka, bahkan kulit dan lain sebagainya. Sama halnya yang tejadi dengan masyarakat Muhammadan yang memang berkulit hitam, mempunyai fisik yang tinggi, dan besar membuat masyarakat sedikit tertutup untuk menjalin komunikasi dengan masyarakat Muhammadan. Tradisi serak gulo ini menghapus image buruk dan rasa takut untuk berinteraksi dengan masyarakat Muhammadan. Masyarakat Muhammadan ternyata mempunyai sifat yang ramah, suka bercanda, dan suka menyapa duluan. Sifat ramah tersebut menjadikan penduduk lain nyaman untuk berinteraksi dengan masyarakat Muhammadan.

b. Meningkatnya Rasa Solidaritas dan Toleransi

Tradisi serak gulo ini mampu untuk menjalin kerjasama baik itu dari kalangan anak-anak, pemuda dan orang dewasa. Keterbukaan ini memberikan dampak persatuan yang akan mengikat serta menguatkan hubungan masyarakat Muhammadan dengan etnis lain. Selama tiga tahun terakhir tidak ada perselisihan yang terjadi, hal ini tidak jauh dari peran dan sifat masyarakat Muhammadan yang selalu terbuka dan mempunyai toleransi yang tinggi kepada sesama. Dapat dirasakan bahwa nilai gotong royong masih terasa kental di Kota Padang, hal tersebut terbukti karena setiap kegiatan kebudayaan yang ada dilingkungan masyarakat selalu datang membantu. Terdapatnya kepedulian sosial menciptakan masyarakat Muhammadan lebih dekat dengan semua masyarakat antar etnis yang ada di Kota Padang.

c. Terjadinya Amalgamasi

Sifat dan komunikasi yang terbuka menjadi faktor penting dalam proses amalgamasi. Keterbukaan yang ada menjadikan masyarakat Muhammadan dan masyarakat lain tidak mempersalahkan adanya perbedaan etnis atau ras malah sebaliknya justru mengakui persamaan hak satu sama lain. Selain faktor diatas, juga terdapat faktor lain dalam menunjang terciptanya amalgamasi, berupa ekonomi, kesamaan agama, dan sosial. Mempunyai kesamaan dalam hal agama justru berdampak baik. Interaksi yang ada karena kesamaan agama bisa terjadi pada pelaksanaan solat berjamaah di masjid Muhammadan. Proses interaksi terjadi tidak melihat bagaimana background budaya dan asal, tetapi bisa membentuk sebuah kedekatan sehingga terbentuk integrasi sosial antar etnis.

\section{Kesimpulan}

Simpulan pada penelitian ini diantaranya yaitu, serak gulo merupakan tradisi warisan turun-temurun yang telah dilaksanakan sejak ratusan tahun yang lalu. Tradisi ini merupakan sebuah kegiatan dalam memperingati hari lahir Sahul Hamid yang diyakini sebagai wali Allah setiap tanggal 31 Jumadil Akhir. Filosofi gula dianggap 
sebagai salah satu simbol keberkahan yang mana mempunyai makna manis, sehingga diharapkan orang yang menerima gula tersebut akan mempunyai kehidupan yang berkah dan manis layaknya gula yang dibagikan. Kegiatan ini bersifat terbuka untuk umum, siapa saja boleh datang dan ikut memeriahkan acara tersebut. Gula yang dikumpulkan juga tidak murni dari masyarakat Muhammadan saja, tetapi juga nazar dari masyarakat etnis lain.

Adapun peran Dinas Pariwisata dan Budaya adalah (1) untuk selalu mendukung setiap kegiatan masyarakat yang berhubungan dengan budaya dalam aspek pelestarian budaya lokal yang ada di Kota Padang, (2) membantu dari segi dana dan pengamanan, (3) memberikan kesempatan untuk eksis di tengah masyarakat kota Padang yang ditampilkan setiap tahun pada tanggal 31 Jumadil Awal. Upaya yang telah dilakukan adalah dengan melibatkan pemerintah pada pelaksaaan tradisi serak gulo dalam bentuk tamu undangan khusus. Biasaya setiap tahun selalu dihadiri oleh Walikota Padang, Wakil Gubernur Sumatera Barat, bahkan Anggota DPR RI beserta jajaran pemerintah lainnya. Selain itu hal yang dapat dilakukan pemerintah adalah memasukkan kegiatan tradisi serak gulo ke dalam kalender tahunan Kota Padang untuk mendapatkan sebuah pengakuan budaya warisan dari masyarakat Muhammadan. Lalu pemerintah menghimbau kepada masyarakat untuk saling menyebarkan informasi terkait pelaksanaan kegiatan serak gulo. Hal yang paling penting yaitu berperan sebagai penyedia sarana dan prasarana.

Adapun kontribusi serak gulo dalam mewujudkan integrasi antar etnis di Kota Padang meliputi (1) meningkatnya interaksi antar masyarakat antar etnis di Kota Padang (2) Menguatnya rasa identitas sebagai bagian dari masyarakat Kota Padang (3) Menguatnya rasa solidaritas dan toleransi antar masyarakat Kota Padang (4) Terjadinya amalgamasi antar etnis. Tradisi ini memberikan nilai-nilai moral yang patut di apresiasi oleh pemerintah. Masyarakat Muhammadan sadar dengan kuantitas penduduknya minoritas tapi tidak menyudutkan keinginan mereka untuk memperkenalkan budayanya kepada masyarakat yang ada di Kota Padang. 


\section{Bibliografi}

Abidin, Zaenal. (2016). Menanamkan Konsep Multikulturalisme di Indonesia. Jurnal Dinamika Global, 1(02), 123-140.

Faisal, Faisal. (2020). TRADISI RITUAL SOSIAL: RUANG PERJUMPAAN LINTAS ETNIS DAN AGAMA. Jurnal Studi Agama, 4(2), 83-98.

Fukuyama, Francis. (2002). Trust: kebajikan sosial dan penciptaan kemakmuran. Language, $19(563 \mathrm{p}), 24 \mathrm{~cm}$.

Hardianto, Hardianto. (2020). Nilai-nilai pendidikan karakter dalam kegiatan keagamaan lembaga dakwah kampus Universitas Mataram Tahun 2020. UIN Mataram.

Hasan, Muhammad Tholhah. (2016). Islam Kita Menuju Islam Rahmatan Lil 'Alamin. Modul Perkuliahan Program Doktor Pendidikan Islam Multikultural Universitas Islam Malang.

Juditha, Christiany. (2015). Stereotip dan Prasangka dalam Konfl ik Etnis Tionghoa dan Bugis Makassar.

Nurhayati, Ifa, \& Agustina, Lina. (2020). Masyarakat Multikultural: Konsepsi, Ciri Dan Faktor Pembentuknya. Akademika, 14(01).

Safwan, Mardanas, Taher, Ishaq, \& Asnan, Gusti. (1987). Sejarah Kota Padang. Direktorat Jenderal Kebudayaan.

Sari, S. O. (2011). Tradisi Serak Gulo Pada Masyarakat Keturunan India Kota Padang (Universita). padang.

Schwandt, Thomas A. (2007). Participatory action research (PAR). The Sage Dictionary of Qualitative Inquiry, 221.

Sugiyono. (2012). Metode Penelitian Kuantitatif, Kualitatif dan R \& D.Bandung:Alfabeta. Metode Penelitian Kuantitatif, Kualitatif Dan $R \quad \&$ D.Bandung:Alfabeta. https://doi.org/10.1017/CBO9781107415324.004

Sugiyono, Metode. (2014). Penelitian Pendidikan Pendekatan Kuantitatif Kualitatif $\underline{\text { R\&D }}$ cet. Ke-19, Bandung: Alfabeta.

Syam, Nur. (2009). Tantangan multikulturalisme Indonesia: Dari radikalisme menuju kebangsaan. Kanisius. 